\title{
The Utilization of Soybean as a Catalyst Material in Enzyme-Mediated Calcite Precipitation (EMCP) for Crack Healing Concrete
}

\author{
Regina Aprilia Zulfikar ${ }^{1, *}$, Heriansyah Putra ${ }^{1, *}$, Hideaki Yasuhara ${ }^{2}$ \\ ${ }^{1}$ Department of Civil and Environmental Engineering, IPB University, Bogor, INDONESIA \\ Jl. Raya Dramaga Kampus IPB Dramaga Bogor, 16680 \\ ${ }^{2}$ Department of Civil and Environmental Engineering, Ehime University, Matsuyama, JAPAN \\ 3-Bunkyo-cho Matsuyama, 790-8577 \\ *Corresponding authors: reginaprilia0@gmail.com; heriansyahptr@apps.ipb.ac.id
}

SUBMITTED 20 July 2020 REVISED 27 August 2020 ACCEPTED 6 October 2020

\begin{abstract}
The effect of using soybean as a catalyst in the Enzyme-Mediated Calcite Precipitation (EMCP) method of crack healing concrete is discussed in this research. The existence of cracks in concrete reduces its quality, therefore, there is the need for repair efforts and one of these is through injection using the EMCP method. This technique employs the plant-derived urease enzyme to catalyze the reaction between calcium chloride $\left(\mathrm{CaCl}_{2}\right)$ and urea $\left(\mathrm{CH}_{4} \mathrm{~N}_{2} \mathrm{O}\right)$ towards precipitating calcium carbonate $\left(\mathrm{CaCO}_{3}\right)$. Its effectiveness was, however, evaluated using a test tube experiment, and the optimum combination of urease, urea, and calcium chloride was selected and used as the preliminary data for the soybean added as a catalyst. Meanwhile, the concrete samples were prepared in the form of $5 \mathrm{~cm} x$ $10 \mathrm{~cm}$ cylindrical concrete and the crack was made through Universal Testing Machine (UTM) with a controlled area observed to be in the range of $\pm 0.2-0.3 \mathrm{~mm}$. The injection solution was added to the concrete using the percolation method up to the period the height of the solution was $5 \mathrm{~mm}$ above the concrete surface and this was conducted several times with the effect on the concrete cracks evaluated through permeability tests which were used as one of the concrete quality parameters. Moreover, the permeability coefficient value was found to be inversely proportional to the quality and this means a smaller value of the coefficient produced better concrete quality and vice versa. The results showed the total calcite formed in the sample after the 4th injection was $18.3 \%$ of the total surface area of the concrete crack and was able to reduce the concrete permeability value by $95.43 \%$. This, therefore, means the use of soybean in the EMCP method is considered feasible to repair concrete cracks.
\end{abstract}

KEYWORDS Crack Healing; EMCP; Grouting; Permeability; Soybean.

(c) The Author(s) 2021. This article is distributed under a Creative Commons Attribution-ShareAlike 4.0 International license.

\section{INTRODUCTION}

Concrete is a heterogeneous material and this means it is highly susceptible to both macro and micro cracks. The difference in concrete quality due to the diversity in the mixture composition and physical properties of the material as well as the existence of loading or some shaking factors usually lead to a high potential for cracks (Paulay and Park 1975). These cracks have the ability to increase the possibility of water and other destructive compounds entering the concrete structure, thereby, causing corrosion and, in the long run, affects the service life of the concrete (Wiktor and Jonkers 2011). This further has effects on the durability of concrete structure in the long term by causing its destruction and, consequently, high losses (Van Tittelboom and De Belie 2013).

There is, therefore, the need to repair the structures before more severe damage is done to the concrete. However, the repair and maintenance of cracks are generally through injection solutions with high viscosity and this presents obstacles to the repair of micro-cracks which are unable to be solved by the healing agents injected from the concrete surface such as an epoxy resin (Herlambang and Setyono 2018) and pressure grouting method using polyurethane (Junianto et al. 2019). This makes it important to study the sustainable methods and strategies to increase the durability of concrete 
(Schlangen and Sangadji 2013). Previous researchers have studied the repair of concrete cracks through bio-mediated soil improvement (MICP, Microbial Induced Calcite Precipitation) (DeJong et al. 2010), inorganically precipitated phosphates (Neupane et al. 2018), resin concrete (Wijaya and Saputra 2017), and self-healing concrete with bacteria having the ability to produce alkali-resistant spore (Achal et al. 2011). It is possible to use the spore to activate the water and oxygen on cracks and the addition of some organic substrates which are metabolized by active bacteria to become calcite has also been reported to be useful in closing the cracks (Tziviloglou et al. 2016). The self-healing method ensures the production of a more durable structure and reduced cost of maintenance (Khaliq and Ehsan 2016). Nevertheless, the hardening process of concrete has an effect on the survival of the bacteria and their death reduces the effectiveness of the self-healing concrete. This, therefore, means the method also has its difficulties due to the special efforts it requires to keep the bacteria alive in concrete to produce $\mathrm{CaCO}_{3}$ as the agent to cover the crack (Achal et al. 2011).

The research by Yasuhara et al. (2011) showed the possibility of forming $\mathrm{CaCO}_{3}$ crystals using the Enzyme-Mediated Calcite Precipitation (EMCP) method which uses a solution with a combination of urease, urea, and calcium chloride $\left(\mathrm{CaCl}_{2}\right)$. Moreover, the carbonate ion generated from the breakdown of urea by urease was later precipitated as a calcium carbonate crystal in the presence of calcium ions and protein content (Neupane et al. 2015). The use of urease in the EMCP method is, however, less economical when applied on a large scale in the field because its procurement costs $>90 \%$ of the fund to be spent on the materials (Baiq et al. 2020). Therefore, there is a need for an alternative material which is environmentally friendly and with the ability to function as a catalyst in the crystallization process of $\mathrm{CaCO}_{3}$ to be used as an agent in repairing concrete cracks.

The urease enzyme is usually used to separate the urea into ammonium and carbonate ions with the carbonate ions precipitated as a calcium carbonate crystal in the presence of calcium ions and protein content. Zhang et al. (2016) showed the protein content has the ability to act as an essential nucleation site for the crystallization of $\mathrm{CaCO} 3$. The focus of this research was, therefore, to use another material in the form of soybean which has a high protein content to catalyze the calcium carbonate crystals formation process. This is possible because Winarsi (2010) reported the community understands the usefulness of soybean based on its nutrition, especially the protein content which is up to $40 \%$ and reported to be equivalent to those of animals despite its vegetable origin. Therefore, there is a need to evaluate the use of soybean as a catalyst in the EMCP method and determine its level of influence on the process of repairing concrete cracks.

\section{MATERIALS AND METHODS}

\subsection{Materials}

The materials used in this study include Portland composite cement (PCC), sand from Cimangkok (Indonesia) as fine aggregate, gravel as coarse aggregate, and water to make concrete. Moreover, urea and $\mathrm{CaCl}_{2}$ with $95 \%$ purity from Kanto Chemicals, Tokyo, Japan, Urease from 020-83242, Kishida Chemical, Osaka, Japan purified from Jack bean meal, and the soybean flour from No.1031PBIOCert/LSO-006-IDN/05 /17 by Gasol Pertanian Organik which was applied as the catalyst were all used in the EMCP method. The reactions for the precipitation of carbonate ions in the solution are shown in Equations (1) to (4):

$$
\begin{aligned}
& \mathrm{CO}\left(\mathrm{NH}_{2}\right)_{2}+\mathrm{H}_{2} \mathrm{O} \stackrel{\text { urease }}{\longrightarrow} 2 \mathrm{NH}_{4}^{+}+\mathrm{CO}_{3}^{2-} \\
& \mathrm{CaCl}_{2} \rightarrow \mathrm{Ca}^{2+}+2 \mathrm{Cl}^{-} \\
& \mathrm{Ca}^{2+}+\mathrm{CO}_{3}^{2-} \rightarrow \mathrm{CaCO}_{3} \\
& 2 \mathrm{NH}_{4}^{+}+2 \mathrm{Cl}^{-} \rightarrow 2 \mathrm{NH}_{4} \mathrm{Cl}
\end{aligned}
$$

\subsection{Methods}

\subsubsection{Material preparation and testing}

The aggregates were tested to obtain their physical properties such as the specific gravity, 
sludge content, and absorption rate. Moreover, the soybean used as the catalyst in the EMCP method was made into soy flour to ensure its easy dissolution and inhibits porosity due to its possible effect on the strength of the concrete. In this case, $100 \%$ soybean flour was used without other additives. The results of the test were subjected to ASTM, SNI, and SII standards before they were entirely made ready for use. The physical properties of the materials are presented in Table 1.

Table 1. The physical properties of the materials

\begin{tabular}{|c|c|c|c|c|}
\hline No & $\begin{array}{l}\text { Material } \\
\text { Parameters }\end{array}$ & $\begin{array}{l}\text { Fine } \\
\text { Agg. }\end{array}$ & $\begin{array}{l}\text { Coarse } \\
\text { Agg. }\end{array}$ & Standards \\
\hline 1 & $\begin{array}{l}\text { Silt content } \\
\text { (\%) }\end{array}$ & 2.15 & 0.53 & $\begin{array}{l}\text { SK SNI S- } \\
04-1989-F\end{array}$ \\
\hline 2 & $\begin{array}{l}\text { Specific } \\
\text { gravity (SSD) }\end{array}$ & 1.90 & 2.06 & $\begin{array}{l}\text { SNI 1969- } \\
2008\end{array}$ \\
\hline 3 & $\begin{array}{l}\text { Water } \\
\text { content (\%) }\end{array}$ & 1.3 & 3 & $\begin{array}{l}\text { (coarse } \\
\text { aggregates) }\end{array}$ \\
\hline 4 & $\begin{array}{l}\text { Absorption } \\
\text { (\%) }\end{array}$ & 0.46 & 2.37 & $\begin{array}{l}\text { and SNI } \\
1970-2008\end{array}$ \\
\hline 5 & $\begin{array}{l}\text { Unit weight } \\
\left(\mathrm{kg} / \mathrm{m}^{3}\right)\end{array}$ & 1680 & 1618 & $\begin{array}{l}\text { (fine } \\
\text { aggregates) }\end{array}$ \\
\hline 6 & $\begin{array}{l}\text { Modulus of } \\
\text { fineness }\end{array}$ & 2.20 & 7.03 & $\begin{array}{l}\text { ASTM C33- } \\
86\end{array}$ \\
\hline
\end{tabular}

\subsubsection{The preparation of concrete}

The fine aggregate was the Cimangkok sand which is included in the moderate category of sand gradation limit no. 2 while the coarse aggregate was closest to the sieve analysis chart with a maximum size of $20 \mathrm{~mm}$. The concrete used was K-200 which is equivalent to fc '16.6 $\mathrm{MPa}$ and those with fc ' $<20 \mathrm{MPa}$ are included in the low strength concrete based on SNI 03-64682000. This normal concrete category was considered sufficient due to the focus of the study on the effect of soybean on the healing of concrete crack with the evaluation conducted through permeability test. It is important to note that the scope of this study did not include the crack healing of mechanical properties. Meanwhile, the concrete sample was prepared using a $5 \mathrm{~cm} \mathrm{x}$ $10 \mathrm{~cm}$ cylindrical mold prepared from PVC as shown in Figure 1

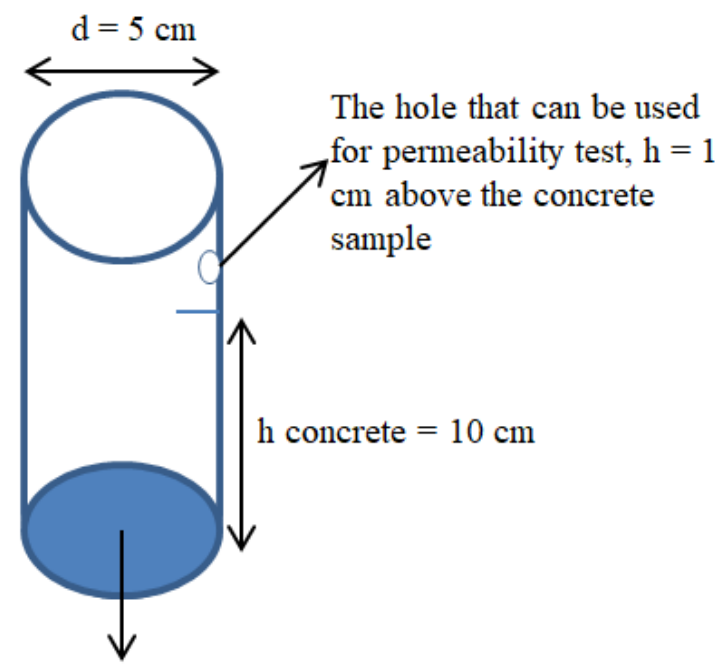

The pipe cover

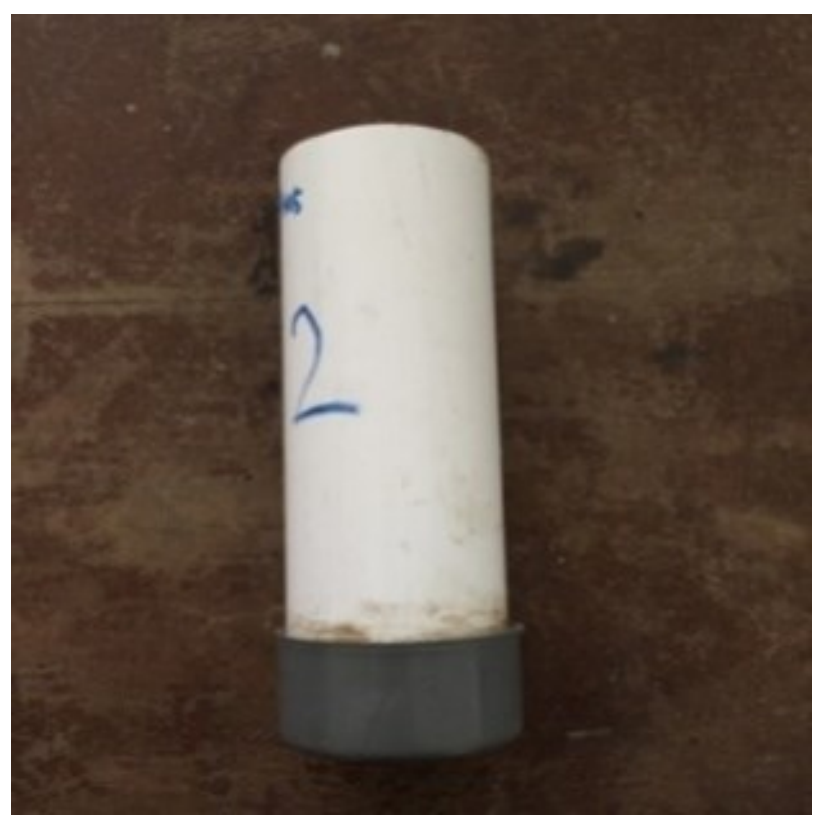

Figure 1. The cylindrical mold from PVC pipe

The proportions of aggregate, cement, and water were obtained from the calculation of the mix design with reference to the SNI 03-2834-2002 standard and the values are indicated in Table 2.

Table 2. The proportion of the materials in the concrete (SNI 03-2834-2002)

\begin{tabular}{lll}
\hline No & Materials & $\begin{array}{l}\text { Proportion }(\mathrm{kg}) \\
\text { in } 1 \mathrm{~m}^{3}\end{array}$ \\
\hline 1 & Cement & 352 \\
2 & Water & 215 \\
3 & Fine aggregate (SSD) & 731 \\
4 & Coarse aggregate (SSD) & 1031 \\
\hline
\end{tabular}




\subsubsection{Curing and testing the samples}

The concrete sample was designed to have a strength of $16.6 \mathrm{MPa}$ and considered sufficient due to the focus of this study on the effect of soybean on crack healing concrete while the evaluation was through a permeability test. Moreover, a confined-splitting strength test was later conducted using a Universal Testing Machine (UTM) to make almost uniform and evenly distributed cracks from the top to bottom of the concrete samples at $\pm 0.2-0.3 \mathrm{~mm}$. These cracks were provided based on the research of Kulkarni et al. (2020) which showed the size of the crack to be sufficient in ensuring the increase of the permeability by an average of $60 \%$. The formation of calcite in the crack area has also been reported to be 15-20\% more than cracks with a width smaller than $0.2 \mathrm{~mm}$ or greater than 0.3 $\mathrm{mm}$. The confined-splitting strength scheme through the use of UTM to provide crack is shown in Figure 2 while the concrete samples tested and cracked at $\pm 0.2-0.3 \mathrm{~mm}$ are presented in Figure 3 .

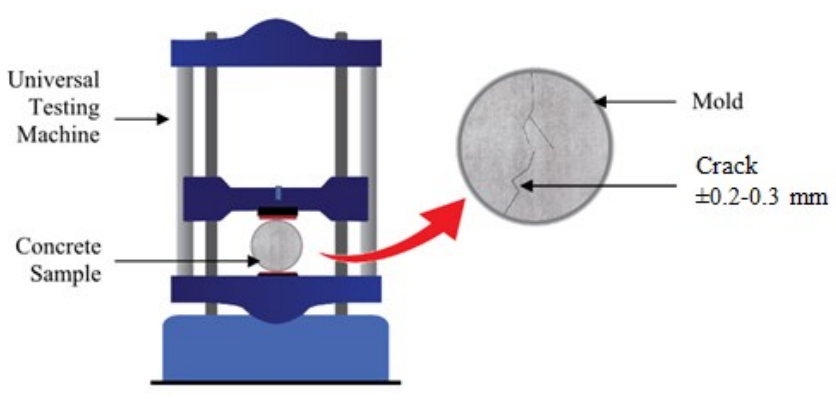

Figure 2. The confined-splitting strength scheme uses the UTM to create cracks
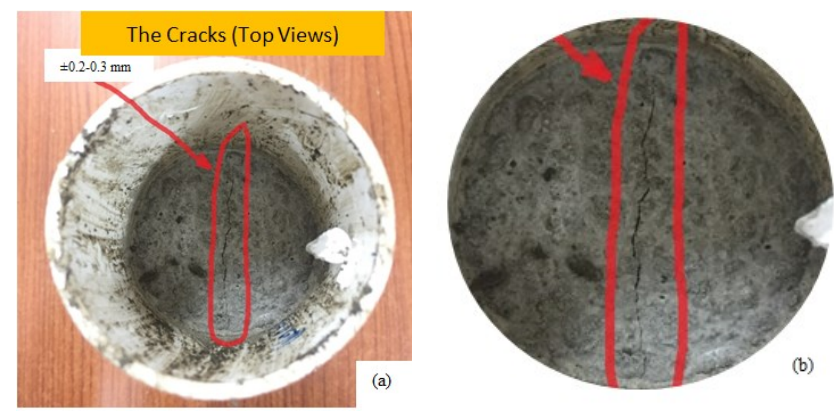

Figure 3. The top and bottom cracks of concrete samples

The concrete samples were made to pass through the curing or maintenance phase by soaking them in a bathtub for one day before the concretes were tested while the maximum maintenance period was 28 days and the samples were not removed during the curing time. Moreover, each of the samples was marked with specific codes to minimize errors in this phase and these include letters BU for solid concrete, BR for cracked concrete without injection, and BI for injected concrete after which numeric codes consisting of the number of injections $0-4$ and the number of samples 1 and 2 were placed beside the letters to produce codes such as BI-12. Furthermore, the samples were removed according to the time of tests or age in order to extract water from the concrete pores after which the permeability test was conducted to determine the percentage of water passing through the control concrete which is without cracks. Another concrete sample was cracked to make a micro-crack and a permeability test was also conducted to determine the percentage of water passing before the crack was repaired.

\subsubsection{The EMCP solution}

The procedure to produce the EMCP solutions was adopted from Putra et al. (2016) and this involved the use of test-tube experiments to evaluate the deposition process and amount of sedimentation. The proportions of $\mathrm{CaCl}_{2}$, urea, and urease concentrations used were $1.00 \mathrm{~mol} / \mathrm{L}$, $1.00 \mathrm{~mol} / \mathrm{L}$, and $2.00 \mathrm{~g} / \mathrm{L}$, respectively while the addition of an alternative ingredient in the form of soy flour as an independent variable was evaluated using different concentrations as indicated in Table 3.

Table 3. Experimental conditions for test tube experiment

\begin{tabular}{lllll}
\hline & \multicolumn{3}{l}{ Concentration } \\
\cline { 2 - 5 } Sample & $\begin{array}{l}\mathrm{CaCl}_{2} \\
(\mathrm{~mol} / \mathrm{L})\end{array}$ & $\begin{array}{l}\text { Urea } \\
(\mathrm{mol} / \mathrm{L})\end{array}$ & $\begin{array}{l}\text { Urease } \\
(\mathrm{g} / \mathrm{L})\end{array}$ & $\begin{array}{l}\text { Soy flour } \\
(\mathrm{g} / \mathrm{L})\end{array}$ \\
\hline $\mathrm{A} 0$ & 1.00 & 1.00 & 2.00 & 0.00 \\
$\mathrm{~A} 1$ & 1.00 & 1.00 & 2.00 & 1.00 \\
$\mathrm{~A} 2$ & 1.00 & 1.00 & 2.00 & 5.00 \\
$\mathrm{~A} 3$ & 1.00 & 1.00 & 2.00 & 10.00 \\
\hline
\end{tabular}

There were 4 variations of the sample with different concentrations of soy flour and each was replicated into other three samples. First, urease and soy flour were mixed with distilled water and 
stirred for 2 minutes. Meanwhile, the reagents including the urea and $\mathrm{CaCl}_{2}$ were also mixed evenly with distilled water until all the particles were dissolved. This was followed by the mixture of the solution with two methods in a different order after which all the samples were allowed to react for 3-7 days of curing time at room temperature to form calcium carbonate crystals. The solution was filtered using filter paper and dried at a temperature of $\pm 60^{\circ} \mathrm{C}$ for 24 hours and weighed to determine the sediment formed. The process of each method is, therefore, simply presented in the test-tube experiment of Figure 4
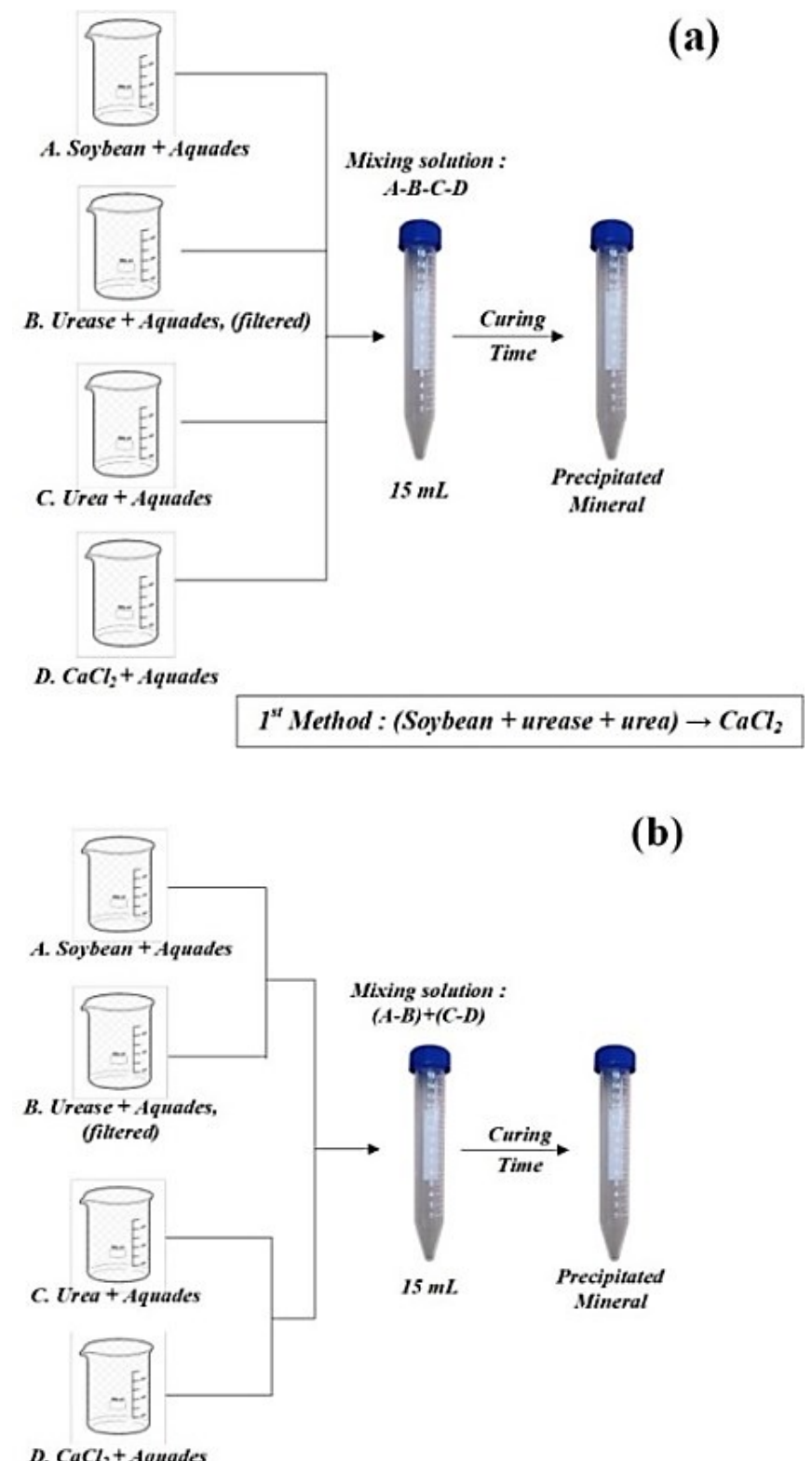

$2^{\text {nd }}$ Method : (Soybean + urease $) \rightarrow\left(\right.$ Urea $\left.+\mathrm{CaCl}_{2}\right)$

Figure 4. The test tube procedures (a) $1^{\text {st }}$ method (b) $2^{\text {nd }}$ method

\subsubsection{The permeability test}

The optimum level of $\mathrm{CaCO}_{3}$ formation obtained from the test tube results was used as a solution to grout the previously cracked concrete through a $5 \mathrm{~mm}$ soak method in the concrete mold. Moreover, the number of grouting was varied for seven days from the $5^{\text {th }}$ to the $26^{\text {th }}$ day to make a total of four grouting times. The injection volume based on the precipitation test was $48 \mathrm{ml}$ of the solution and the concrete mold was confirmed not to be leaking to ensure none of the solutions was wasted. Furthermore, a permeability test was conducted using the flow test method to determine the percentage of water passing through the concrete. The results obtained were in the form of flow rate and pressure and were used to calculate the concrete permeability coefficient. All the samples including the whole concrete (BU) used as the control was tested on the 0th and 28th day, cracked concrete without injection (BR) used as the cracked control without injection for repair was also tested on the 0th and 28th day while the injected cracked concrete (BI) was repaired by injection using the optimum EMCP solution injected 4 times which were the 5th, 12th, 19th, and 26th day and also tested for permeability every two days after the injection was provided -7 th, 14 th, 21st, and 28 th day. A simple sketch of the permeability test instrument and procedure is presented in Figure 5.

The permeability was tested to determine the percentage of water escaping into the concrete and the flow test method used was based on the results of the research by Sugiharto et al. (2004) while the test equipment manufacturer was with reference to Neupane et al. (2018). Moreover, the test equipment used includes water tanks, hoses, molds, measuring tubes, and scales with the water tanks placed at a certain height to ensure differences in the altitude. The concrete mold was specially designed with a hose hole at the bottom to drain water from the tank while the top part was equipped with a tap to ensure the drain water passing through the concrete to enter the measuring tube. Furthermore, the measuring tube filled with water was placed on the scale to determine the volume of water escaping the concrete. The data in the relationship graph of 
the number of injections to the percentage of water escaping the concrete were, however, analyzed after the injection and permeability tests. The concrete permeability coefficient values were calculated using the Darcy Equation as presented in Equation (5) (Bungey and Grantham 2006).

$k=\frac{\rho g L Q}{P A}$

where $k$ is the concrete permeability coefficient $(\mathrm{cm} / \mathrm{s}), \rho$ is water density $\left(\mathrm{kg} / \mathrm{cm}^{3}\right), g$ is the acceleration of gravity $\left(\mathrm{cm} / \mathrm{s}^{2}\right), L$ is the sample length/height $(\mathrm{cm}), Q$ is the flow rate $\left(\mathrm{cm}^{3} / \mathrm{sec}\right), P$ is the water pressure $\left(\mathrm{kg} . \mathrm{cm} / \mathrm{sec}^{2} / \mathrm{cm}^{2}\right)$, and $A$ is the sample cross-sectional area $\left(\mathrm{cm}^{2}\right)$.

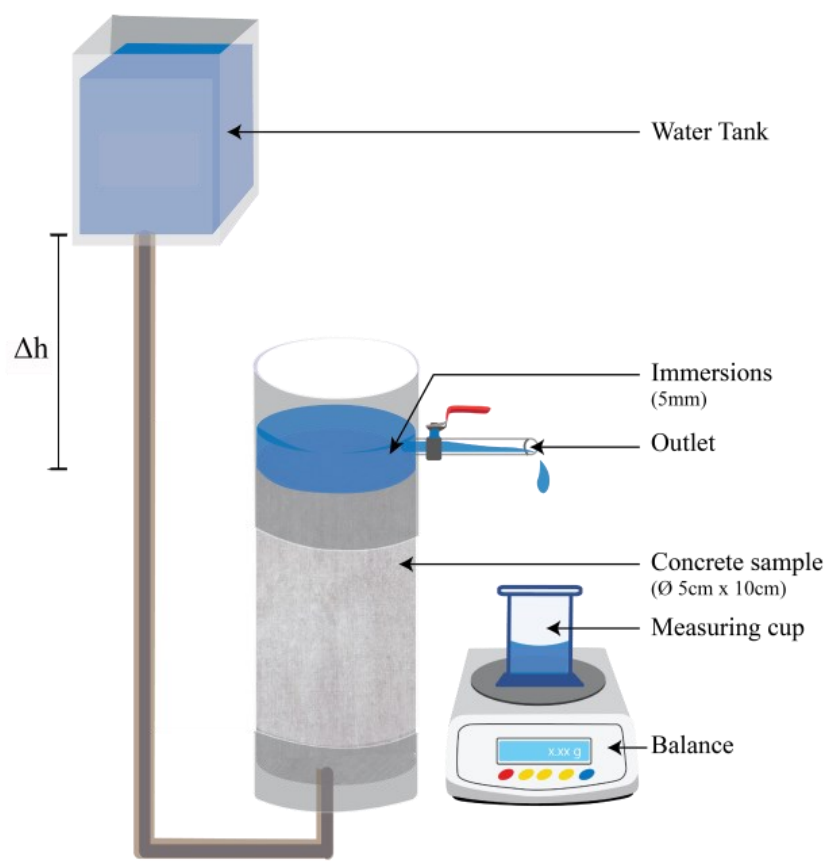

Figure 5. Permeability test instrument and procedure

\section{RESULTS AND DISCUSSION}

\subsection{Test Tube}

The hydrolysis reactions expected from the Enzyme-Mediated Calcite Precipitation (EMCP) method are presented in Equations (1) to (4). Moreover, the addition of the urease enzyme was to break the urea into carbonate and ammonium ions while the dissolution of calcium chloride $\left(\mathrm{CaCl}_{2}\right)$ in water was to produce calcium and chloride ions. The calcium carbonate $\left(\mathrm{CaCO}_{3}\right)$ was formed based on the reaction of carbonate and calcium ions which happened due to the mixture of the solution. Meanwhile, the effect of the soy flour used was evaluated through two methods while the calcium carbonate (calcite) crystals formed from the two methods of the EMCP test tube are presented in Figure 6.

Figure 6 shows the calcite formed in each variation of soybean flour concentration using two different methods. The results have been corrected before the solubility curve for the soybean flour particles was obtained and the amount of calcite $1 \mathrm{gr} / \mathrm{L}$ soybean was observed to have decreased, later increased at $5 \mathrm{gr} / \mathrm{L}$, and reduced again at $10 \mathrm{gr} / \mathrm{L}$ for the $2^{\text {nd }}$ method. This means the optimum amount of calcite formed using this method was 1.57 grams which is a variation of $5 \mathrm{gr} / \mathrm{L}$ concentration. Meanwhile, the solution mixed with the $1^{\text {st }}$ method was observed to have decreased at different concentrations of 1 gr/L while the quantity of calcite continued to increase at $5 \mathrm{gr} / \mathrm{L}$ and $10 \mathrm{gr} / \mathrm{L}$. Therefore, the optimum amount of calcite formed in this method was 2.03 grams which is a variation of $10 \mathrm{gr} / \mathrm{L}$.

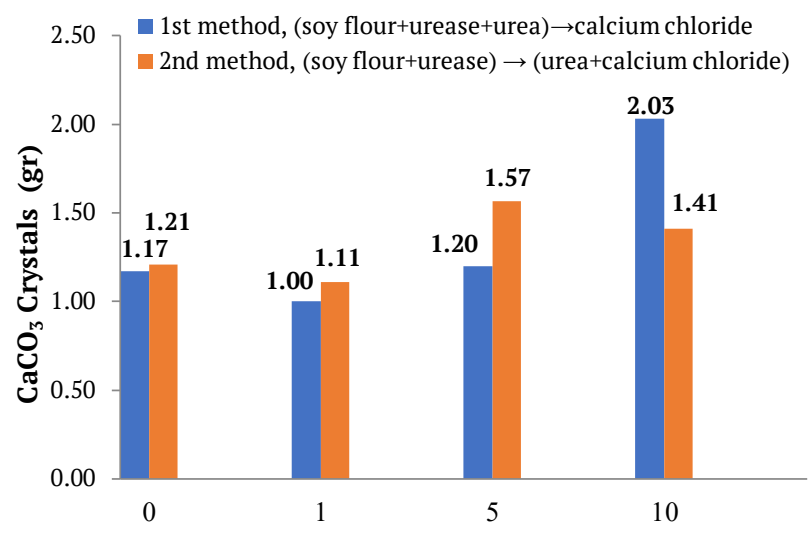

The Variations of Soy Flour Concentration (gr/L)

Figure 6. The diagram of $\mathrm{CaCO}_{3}$ crystals results based on test tube

Figure 6 also shows the control solution with 0 gr/L of soy flour has more calcite formation through the use of the $2^{\text {nd }}$ method with the difference between the methods observed to be $3.3 \%$. This is associated with the mixture of the urea and $\mathrm{CaCl}_{2}$ solutions first into the reagent solution to ensure quick reaction in producing lime in the $2^{\text {nd }}$ method. This means the method is more efficient compared to the separate 
dissolution of the urea and $\mathrm{CaCl}_{2}$ as observed in the $1^{\text {st }}$ method due to the presence of time lag which affects the efficiency of the $\mathrm{CaCO}_{3}$ formation (Putra et al. 2017). Similarly, the $2^{\text {nd }}$ method produced more calcite than the $1^{\text {st }}$ at a difference of $9.9 \%$ and $23.56 \%$ in the variation of 1 and $5 \mathrm{gr} / \mathrm{L}$ soybean flour concentrations. This shows the addition of a small amount of soy flour solution did not have a significant effect on the hydrolysis reaction and this further makes the $2^{\text {nd }}$ method to be more efficient in producing calcite.

In contrast, the $10 \mathrm{gr} / \mathrm{L}$ concentration of soybean flour was observed to have produced more calcite in the $1^{\text {st }}$ method than the $2^{\text {nd }}$ with a significant difference reaching $30.54 \%$. The research by Saboury and Moosavi-Movahedi (1997) showed fluorine $(F)$ reacts to bind with urease enzyme and due to the fact that it belongs to the same class, halogen, with chlorine the same reaction is expected. This is in line with the findings of Scerri and Eric (2008) that the elements in one group have the same physical or chemical characteristics in their outer electron shells and the same core charge and this means the chloride ion in $\mathrm{CaCl}_{2}$ also has the ability to bind with the urease enzyme. The findings of this study showed the amount of $\mathrm{CaCO}_{3}$ crystals formed in the $2^{\text {nd }}$ method reduced due to the binding of some crude urease in soybeans s to the chloride ions and this led to the reduction of the crude urease required to break down the urea. Meanwhile, the urease and soy flour broke down the urea first as a whole to form carbonate ions the $1^{\text {st }}$ method to ensure the chloride ions slightly bind crude urease to soybeans when the $\mathrm{CaCl}_{2}$ is mixed to produce more calcite.

The precipitation of the calcite formed in 0 to 10 gr/L soybean concentrations was evaluated. This was necessary because at values $>10 \mathrm{gr} / \mathrm{L}$ each concentration increases per 5 gr/L usually lead to an increment in the amount of insoluble soybean flour by $33.3 \%$ based on the solubility curve in Appendix 1. This further makes the sediment produced to be dominated by insoluble soy flour and this consequently interferes with the expected precipitation of calcite. Therefore, the variations in the $10 \mathrm{gr} / \mathrm{L}$ concentration using the $1^{\text {st }}$ method produced the most optimum quantity and used as the concentration in the injection solution to repair the concrete cracks.

\subsection{Permeability Test for Concrete}

\subsubsection{Flow rate}

The permeability test produced the data on the number of volumes produced per unit time which is known as the flow rate for each concrete sample of BU, BR, and BI as shown in Figure 7.

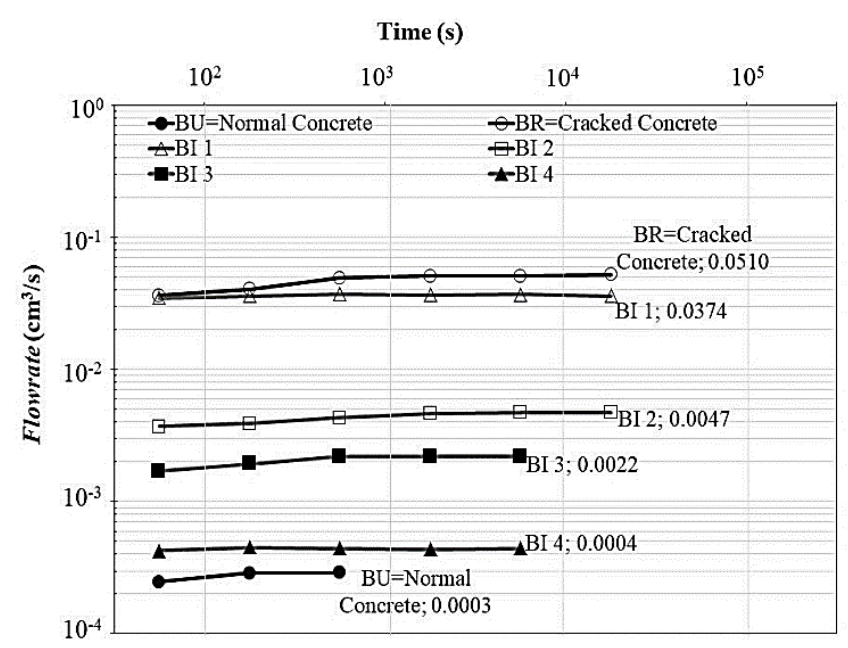

Figure 7. The flow rate graph

Each graph contains the information on the flow rate at each measurement time which was obtained from the volume of water at $\mathrm{cm}^{3}$ which passes per unit time in seconds. The number contained in the curve is the number of flow rates which started to become constant with the average calculated and used to estimate the concrete permeability coefficient (k). Figure 7 shows the average flow rate observed to be the constant in normal concrete samples was 0.0003 $\mathrm{cm}^{3} / \mathrm{s}$ while the cracked concrete samples without injection had $0.0510 \mathrm{~cm}^{3} / \mathrm{s}$. Meanwhile, the magnitudes of the average constant flow rates were $0.0374,0.0047,0.0022$, and $0.0004 \mathrm{~cm}^{3} / \mathrm{s}$, and a very significant increase was observed in the flow rate from the concrete to crack concrete without injection. This is in line with the findings of Wang et al. (2011) that the cracks in concrete increased the amount of escaped water and the time needed to accelerate, thereby, causing the flow rate to increase. The same was also found 
with Hosoda et al. (2009) that the cracks with an average of $0.28 \mathrm{~mm}$ in concrete were able to increase water discharge by up to $20.3 \%$.

\subsubsection{The concrete permeability coefficient}

The concrete permeability coefficient $(\mathrm{k})$ is the level of water allowed to flow through the concrete (Sugiharto et al. 2004). According to Sudipta and Sudarsana (2009), the concrete permeability coefficient is inversely proportional to the concrete strength value such that a smaller value $\mathrm{k}$ usually produces a higher concrete strength and vice versa. The $\mathrm{k}$ value was, however, obtained by using Equation (5) for calculation and the relationship it has with the number of injections is represented in the graph of Figure 8. Moreover, the average of the two samples for each of the variations of $\mathrm{BU}, \mathrm{BR}$, and $\mathrm{BI} 1,2,3$, and 4 was calculated and used in the graph.

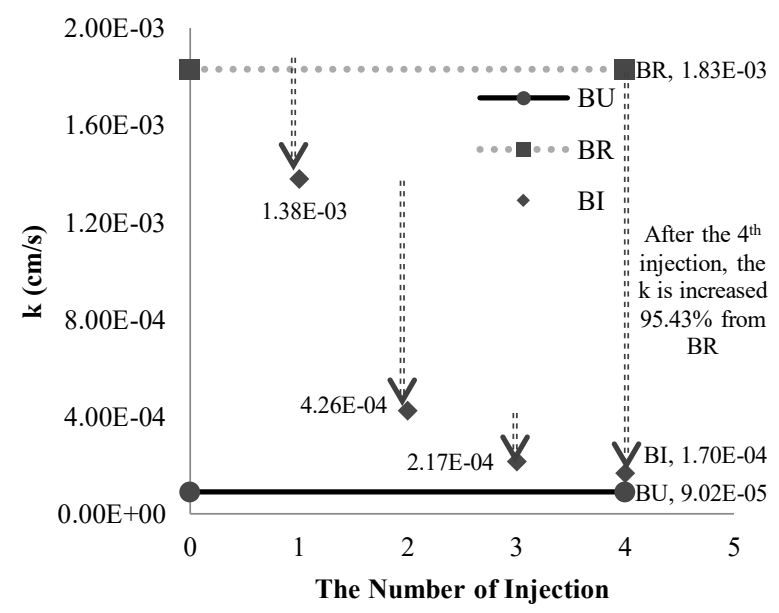

Figure 8. The graph of the relationship between $k$ and the number of injections.

The graph of Figure 8 shows the value of $k$ in a solid concrete sample (BU) was $9.02 \times 10^{-5} \mathrm{~cm} / \mathrm{s}$ while the cracked concrete without injection (BR) had $1.83 \times 10^{-3} \mathrm{~cm} / \mathrm{s}$. The cracks contained in the concrete were $0.2 \mathrm{~mm}-0.3 \mathrm{~mm}$ and the value of $\mathrm{k}$ was found to be 20.3 times the value in concrete without cracks. This is in line with the findings of
Van Tittelboom et al. (2010) that an average crack width of $0.15 \mathrm{~mm}$ increased permeability up to 10 times. Meanwhile, the cracked concrete sample injected (BI) one time had a $\mathrm{k}$ value which was reduced by $24.43 \%$ in comparison with the cracked concrete while the reduction in those injected twice was $69.21 \%$ but those injected three and four times were observed to have a small decrease of only $21.67 \%$. This means the percentage of crack healing was faster at the $1^{\text {st }}$ and $2^{\text {nd }}$ injection and later slowed down at the $3^{\text {rd }}$ and $4^{\text {th }}$ the initial injection and this was associated with the ease penetration of the EMCP solution through wider cracks in the initial injection to allow the calcite formed to close the cracks and significantly reduce the permeability. Meanwhile, some of the cracks have been blocked by calcite formed at the initial injection thereby leaving only a few gaps to be filled by the final injection and this led to a small decrease in permeability. The sample with the $4^{\text {th }}$ injection was discovered to have a $95.43 \%$ reduction of the cracked concrete sample as the maximum and this made the difference from the solid concrete without cracks to be only $4.57 \%$. This is considered efficient enough because it has been reported that a $100 \%$ reduction in permeability is unachievable due to the non-healing process of all cracks through the method (Chen et al. 2019).

The $\mathrm{CaCO}_{3}$ crystals formed were quantified based on the research by Kulkarni et al. (2020) for the injection samples that have been tested for permeability. Meanwhile, the quantity of the $\mathrm{CaCO}_{3}$ deposited was used to determine the crack width and expressed as a percent of the total surface area of the crack. The values for the injected cracked samples (BI) from 1 to 4 in a row were recorded to be $0.264,0.278,0.292$, and 0.316 $\mathrm{mm}$. The relationship between the number of injections, the percentage of calcite, and the value of permeability is, however, presented in Figure 9. 


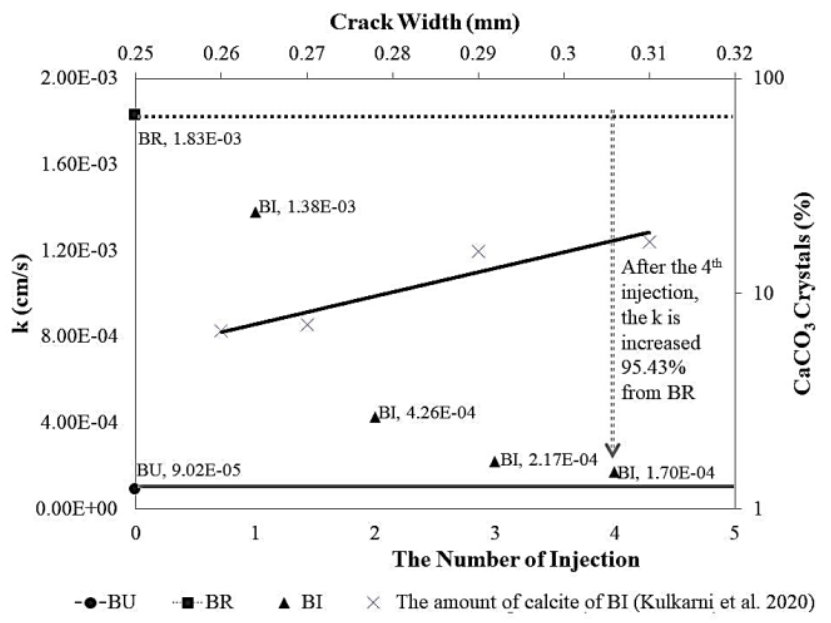

Figure 9. The graph of the relationship between the number of injections, the amount of calcite, and permeability

Figure 9 shows the calcite formed in each sample was $7.6 \%, 9.9 \%, 13.6 \%$, and $18.3 \%$ after the data have been compared. The percentage of the calcite covering the cracks was observed to be increasing with an increment in the number of injections and this was assumed to be due to the production and subsequent accumulation of calcite deposits by each injection Therefore, the optimum percentage of the calcite formed was found to be $18.3 \%$ of the crack surface area of $0.316 \mathrm{~mm}$ after the $4^{\text {th }}$ injection. The covering of the cracks by the calcite eventually led to a decrease in permeability due to the gradual closure of the gap used by the water for infiltration. This reduction happened at each injection and calcite up to $18.3 \%$ was observed to have the ability to reduce $95.43 \%$ permeability value of the cracked concrete without injection on the 4 th injection.

\section{CONCLUSION AND RECOMMENDATION}

This research showed the optimum composition of the soybean flour injection solution to be used as a catalyst with the EMCP method was $10 \mathrm{gr} / \mathrm{L}$ soybean concentration produced using the $1^{\text {st }}$ method. The injection volume based on the precipitation test was found to be $48 \mathrm{ml}$ of the solution and the concrete mold was confirmed not to be leaking to avoid wastage. Furthermore, the total calcite formed in the sample after injecting four times with the EMCP soybean flour method was $18.3 \%$ of the total surface area of the concrete crack and it was able to reduce the concrete permeability value by $95.43 \%$.

It was, however, recommended that future studies should conduct the injection process on the 5th, 12th, 19th, and 26th day due to the possibility of a reaction in the cement at these times. Further research should also be focused on identifying the crude urease in soy flour according to biochemistry, especially with the emphasis on how protein bonds occur and their effect when allowed to react with the halogen group, more specifically, the chloride ion. Moreover, it is also necessary to specifically identify the quantification and location of calcium carbonate formed using X-ray Diffraction (XRD) and Scanning Electron Microscope (SEM) due to the inability of the author to identify the compound because of the availability of limited tools.

\section{DISCLAIMER}

The authors declare no conflict of interest.

\section{FUNDING}

This research was funded by the Ministry of Research and Technology/National Research and Innovation Agency of Republic Indonesia, grant number 1/E1/KP.PTNBH/2020.

\section{ACKNOWLEDGMENTS}

The authors appreciate the Rock Mechanics Laboratory of Ehime University for supporting this research.

\section{REFERENCES}

Achal, V., Mukherjee, A., Reddy, M.S. 2011a. Effect of calcifying bacteria on permeation properties of concrete structures. Journal of Industrial Microbiology and Biotechnology. 38(1), pp. 1229-1234.

Achal, V., Mukherjee, A., Reddy, M.S. 2011b. Microbial concrete: Way to enhance the durability of building structures. Journal of Materials in Civil Engineering. 23(6), pp. 730-734.

Baiq, H.S., Yasuhara, H., Kinoshita, N., Putra, H., \& Johan, E. 2020. Examination of calcite 
precipitation using plant-derived urease enzyme for soil improvement. International Journal of GEOMATE. 19 (72), pp. 231-237.

Badan Standardisasi Nasional. 2002. Tata Cara Pembuatan Rencana Campuran Beton Normal. SNI-03-2834-2002. Jakarta : Badan Standardisasi Nasional.

Bungey, J.H. \& Grantham, M.G. 2006. Testing of Concrete in Structures,

Chen, H.J., Peng, C.F., Tang, C.W., \& Chen, Y.T. 2019. Self-healing concrete by biological substrate. Materials. 12(24), pp. 4099.

DeJong, J.T., Mortensen, B.M., Martinez, B.C., \& Nelson, D.C. 2010. Bio-mediated soil improvement. Ecological Engineering. 36(2), pp. 197-210.

Sugiharto, H., Surya, A., Wibowo, K., \& Tjong, W.F. 2004. Rancang Bangun Alat Uji Permeabilitas Beton. Civil Engineering Dimension. 6(2), pp. 94-100.

Junianto, A., Ramadhan, R.M., \& Utari, J.P. Menggunakan Metode Pressure Grouting dengan Material Polyurethane dan Epoxy ( Studi Kasus : Ruas Jalan Patriot - Perintis Kemerdekaan Kota Pekalongan ). Wahana TEKNIK SIPIL. 24(1), pp. 19-32.

Sudipta, I.K., \& Sudarsana, K. 2009. Permeabilitas Beton dengan Penambahan Styrofoam. Jurnal Ilmiah Teknik Sipil. 13(2), pp. 192-198.

Khaliq W. \& Ehsan, M.B. 2016. Crack healing in concrete using various bio influenced self-healing techniques. Construction and Building Materials. 102(1), pp. 349-357.

Kulkarni, P.B., Nemade, P.D., \& Wagh MP. 2020. Healing of Generated Cracks in Cement Mortar Using MICP. Civil Engineering Journal. 6(4), pp. 679-692.

Neupane, D., Yasuhara, H., Kinoshita, N., \& Ando, Y. 2015. Distribution of mineralized carbonate and its quantification method in enzyme mediated calcite precipitation technique. Soils and Foundations. 55(2), pp. 447-457.
Neupane, D., Yasuhara, H., Putra, H., \& Kinoshita, N. 2018. Inorganically Precipitated Phosphates and Carbonates to Improve Porous Material Properties. EPI International Journal of Engineering. 1(1), pp. 1-6.

Putra, H., Yasuhara, H., Kinoshita, N., Neupane, D., \& Lu, C.W. 2016. Effect of magnesium as substitute material in enzyme-mediated calcite precipitation for soil-improvement technique. Frontiers in Bioengineering and Biotechnology. 4(37), pp. 1-8.

Putra, H., Yasuhara, H., \& Kinoshita, N. 2017. Optimum condition for the application of enzyme-mediated calcite precipitation technique as soil improvement method. International Journal on Advanced Science, Engineering and Information Technology.7(6), pp. 2145-2151.

Saboury, A.A \& Moosavi-Movahedi, A.A. 1997. A simple novel method for determination of an inhibition constant by isothermal titration microcalorimetry. The effect of fluoride ion on urease. Journal of Enzyme Inhibition. 12(4), pp. 273-279.

Schlangen, E. \& Sangadji, S. 2013. Addressing Infrastructure Durability and Sustainability by Self Healing Mechanisms - Recent advances in self healing concrete and asphalt. In Procedia Engineering. (54), pp. 39-57.

Herlambang, F.S., \& Setyono, Y.E,. Analisis Injeksi Epoxy pada Perbaikan Retak Beton Terhadap Beban Lentur. 2018. Wahana Teknik Sipil. 23(2), pp.47-55.

Tziviloglou E, Wiktor V, Jonkers HM, \& Schlangen E. 2016. Bacteria-based self-healing concrete to increase liquid tightness of cracks. Construction and Building Materials. 122(1), pp. 118-125.

Van Tittelboom, K., De Belie, N., De Muynck, W., \& Verstraete, W. 2010. Use of bacteria to repair cracks in concrete. Cement and Concrete Research. 40(1), pp. 157-166.

Van Tittelboom, K. \& De Belie, N. 2013. Selfhealing in cementitious materials-a review. Materials. 6(1), pp. 2182-2217. 
Wijaya, R.A. \& Saputra, A. 2017. Repairing and Retrofitting of Earthquake-Affected Exterior Beam-Column Connection by Using Resin Concrete. Journal of the Civil Engineering Forum.2(2):63-74.

Wiktor, V. \& Jonkers, HM. 2011. Quantification of crack-healing in novel bacteria-based selfhealing concrete. Cement and Concrete Composites, pp. 763-770.

Yasuhara, H, Hayashi, K, \& Okamura, M. 2011.
Evolution in mechanical and hydraulic properties of calcite-cemented sand mediated by biocatalyst. In Geotechnical Special Publication. 52 (3), pp. 539-549.

Zhang, J.L., Wu, R.S., Li, Y.M., Zhong, J.Y., Deng, X, Liu, B., Han, N.X., \& Xing, F. 2016. Screening of bacteria for self-healing of concrete cracks and optimization of the microbial calcium precipitation process. Applied Microbiology and Biotechnology. 100(1), pp. 6661-6670. 
[This page is intentionally left blank] 